\section{FDA Approves New Sterilants}

Historically, the Environmental Protection Agency (EPA) was the agency of the federal government that registered liquid chemical germicides formulated as sterilantsdisinfectants. There were approximately 40 formulations on the market. When the EPA and the Food and Drug Administration (FDA) recently agreed that sterilants and disinfectants intended to be used on medical devices would be the responsibility of the FDA, the agency required all formulations to be cleared by the $510(\mathrm{k})$ process. As a result, there are fewer formulations on the market.

Two new liquid sterilant-disinfectants, Sporox $(7.5 \%$ hydrogen peroxide; Reckitt and Colman, Inc, Montvale, NJ) and Peract TM 20 (0.8\% peroxyacetic acid and 1.0\% hydrogen peroxide; Minntech Corp, Minneapolis, MN), recently were cleared by the FDA for reprocessing medical instruments, including endoscopes. Peract TM 20 sterilant's claim is 8 hours at $20^{\circ} \mathrm{C}$, maximum reuse of 14 days; high-level disinfection claim, 25 minutes at $20^{\circ} \mathrm{C}$, maximum reuse of 14 days. No activation required for $0.08 \%$ peracetic acid/1\% Sporox sterilant claim, 6 hours at room temperature; high-level disinfection claim, 30 minutes at room temperature; 21-day reuse life, no activation required.

Other sterilants and high-level disinfectants cleared by the FDA in a $510(\mathrm{k})$ as of October 28,1997 , with general claims for processing reusable medical and dental devices include Cottrell Limited Procide 14 (2.4\% gluteraldehyde; Cottrell Limited, Englewood, CO) sterilant's claim is 10 hours at $20^{\circ} \mathrm{C}$, maximum reuse of 14 days; highlevel disinfection claim, 45 minutes at $20^{\circ} \mathrm{C}$, maximum reuse of 14 days. Omnicide Long Life Activated Dialdehyde Solution (2.4\% gluteraldehyde) sterilant's claim is 10 hours at $20^{\circ} \mathrm{C}$, maximum reuse of 28 days; high-level disinfection claim, 45 minutes at $20^{\circ} \mathrm{C}$, maximum reuse of 28 days. Omnicide Plus (3.4\% gluteraldehyde) sterilant's claim is 10 hours at $20^{\circ} \mathrm{C}$, maximum reuse of 28 days; high-level disinfection claim, 45 minutes at $20^{\circ} \mathrm{C}$, maximum reuse of 28 days. Cidex Activated Dialdehyde Solution (2.4\% gluteraldehyde; Johnson \& Johnson Medical Products, Inc, Arlington, TX) sterilant's claim is 10 hours immersion at $25^{\circ} \mathrm{C}$, maximum of 14 days reuse; high-level disinfection claim, 45 minutes at $25^{\circ} \mathrm{C}$, maximum of 14 days reuse. Cidex Formula 7 Long-Life Activated Dialdehyde solution (2.5\% gluteraldehyde) sterilant's claim is 10 hours at $20^{\circ}$ $25^{\circ} \mathrm{C}$, maximum reuse of 28 days; high-level disinfection claim, 90 minutes at $25^{\circ} \mathrm{C}$, maximum reuse of 28 days. Cidex Plus 28 Day Solution (3.4\% gluteraldehyde) sterilant's claim is 10 hours at $20^{\circ}-25^{\circ} \mathrm{C}$, maximum reuse of 28 days; high-level disinfection claim, 20 minutes at $25^{\circ} \mathrm{C}$, maximum reuse of 28 days. Metrex Research, Inc, Metricide Activated Dialdehyde Solution (2.6\% gluteraldehyde; Orange, CA) sterilant's claim is 10 hours at $25^{\circ} \mathrm{C}$, maximum reuse of 14 days; high-level disinfection claim, 45 minutes at $25^{\circ} \mathrm{C}$, maximum reuse of 14 days. Metricide Plus 30 Long-Life Activated Dialdehyde Solution (3.4\% gluteraldehyde) sterilant's claim, 10 hours at $25^{\circ} \mathrm{C}$, maximum reuse of 28 days; high-level disinfection claim, 90 minutes at $25^{\circ} \mathrm{C}$, maximum reuse of 28 days. Metricide 28 Day Long-Life Activated Dialdehyde Solution (2.5\% gluteraldehyde) sterilant's claim is 10 hours at $25^{\circ} \mathrm{C}$, maximum reuse of 28 days; high-level disinfection claim, 90 minutes at $25^{\circ} \mathrm{C}$, maximum reuse of 28 days. Wave Energy Systems Wavicide-01 (2.5\% gluteraldehyde; Wayne, NJ) sterilant's claim, 10 hours at $22^{\circ} \mathrm{C}$, maximum reuse of 30 days; high-level disinfection claim, 45 minutes at $22^{\circ} \mathrm{C}$, maximum reuse of 30 days. STERIS Corporation STERIS 20TM Sterilant $(0.2 \%$ peracetic acid; Mentor, $\mathrm{OH}$ ) sterilant's claim is 12 minutes between $50^{\circ}-56^{\circ} \mathrm{C}$, single use only; cleared for use only with the STERIS System 1TM Processor.

FROM: FDA Center for Radiologic Health Home Page.

\section{Use of Teicoplanin for Prevention of Central Venous Catheter Infections}

Ljungman and co-investigators from the Huddinge University Hospital, Karolinska Institutet, Sweden, recently described a prospective, randomized, open study comparing two doses of teicoplanin with no therapy administered at the time of insertion of a central venous catheter that was performed in patients with hematological malignancies and in patients scheduled to undergo allogeneic or autologous stem cell transplantation. The study was designed as a group sequential study. At predetermined intervals, statistical analysis was performed for the main efficacy variable, which was the number of days to treatment failure. Sixty-five patients were randomized. Three patients were judged not to be evaluable. Baseline characteristics were identical in the two groups.

No differences were found in overall infections, bacteremias, gram-positive infections, or local infections between the teicoplanin and control groups. Teicoplanin given at the time of insertion of central venous catheters did not reduce the risk of bacteremias or other line-associated infections.

FROM: Ljungman P, Hagglund H, Bjorkstrand B, Lonnqvist B, Ringden O. Preoperative teicoplanin for prevention of gram-positive infections in neutropenic patients with indwelling central venous catheters: a randomized, controlled study. Support Care Cancer 1997;5:485-488.

Additional news items in this issue: HBV Vaccination of HCWs: Report Card, page 167; Staffing Ratio Has Impact on Risk of Nosocomial Infections, page 180; CDC's Immunization Practices Advisory Committee Revises Vaccine Recommendations for HCWs, page 190; Control of Legionella pneumophila in Hospital Hot-Water Supply, page 214. 